\title{
THE COMPLEXITY OF IDENTITY FORMATION OF BLACK LEARNERS ATTENDING HISTORICALLY WHITE SCHOOLS
}

\author{
Anthony Mpisi ${ }^{1}$, \& Gregory Alexander ${ }^{2}$ \\ ${ }^{1}$ Department of Education, Sol Plaatje University (South Africa) \\ ${ }^{2}$ Department of Post Graduate Studies, Central University of Technology (South Africa)
}

\begin{abstract}
This purpose of this paper is to examine the complexity of identity formation experienced by black learners attending historically white high schools in the Northern Cape. Black South Africans were considered and treated as both intellectually and racially inferior during the apartheid years. This may have created an identity dilemma for a number of generations of South African blacks. The situation was further exacerbated, when black learners were admitted to historically white schools. The staff component (mostly white) of historically white schools appeared to be inadequately prepared for these drastic changes. Consequently, the school that should normally contribute to developing a positive identity formation of learners, seemingly had the opposite effect on black learners. An empirical investigation, by way of the quantitative research method was employed, to ascertain the perceived effect historically white schools have on the identity formation of black learners attending these schools. Some of the findings of this study indicate the manifestation of negative influences, low educator expectations, the disjuncture between the home- and school education, as well as the high failure and drop-out rate, of black learners, as having an effect on the identity formation of black learners. Certain suggestions are made as to how to address the situation.
\end{abstract}

Keywords: Learners, white schools, identity formation.

\section{Introduction}

In South Africa the official and formal segregation of schools along racial and ethnic lines commenced in 1948, when the Nationalist Party came to power. The racial, ethnic and geographical separations within the education system led to the birth of 15 separate education departments, until before 1994. The advent of a democratic made it possible for black learners to enrol at historically white schools. Many of these schools who previously exclusively catered for learners from monocultural background responded by adopting an assimilation approach. Matters were further compounded by the fact that the majority of the educators in the Northern Cape were predominantly white, while black educators only constituted $41 \%$ of the permanently employed teaching staff (Northern Cape Department of Education, EMIS, 2020). However, failure by historically white school to maintain a healthy balance between enculturation, acculturation and de-culturation may prove to be confusing to the black learner. This confusion may in turn hamper the development of a positive identity formation for the black learner, (Ntuli, 1998:9). This study primarily explored influence attending historically white schools has on the identity formation of black learners in Northern Cape high schools.

\section{Aim of paper}

This paper reports on complexity of identity formation of black learners attending historically white schools.

\section{Research methodology}

The study adopted a quantitative research method located in the Social-learning theory research paradigm. Data was collected from 832 black high school learners by way of a self- designed 4-point Likert scale questionnaire to determine the complexity associated with identity formation of these learners attending historically white schools in the Northern Cape. Permission to conduct the empirical study was 
sought from the Northern Cape Education Department, school principals and learners of these specific schools. This aim of this paper is to report on a certain part (10 items) of the questionnaire which has bearing on identity formation in historically white schooling context.

\section{Analysis and discussion of results}

While the study focusses on the South African schooling context, the findings could be relevant to the other parts of the world, as issues of diversity and identity formation remains a challenge, particularly amongst perceived marginalised groupings. The questionnaire completed by these learners contained questions relating to identity formation in a historically white high schooling context. Table 1 presents a summary of how learners responded. Table 1 is a summary of the response of participating learners. We only discuss the most relevant findings relating to identity formation.

Table 1. Summary of learners' responses in relation to questions about identity formation in historically white schooling context.

\begin{tabular}{|c|c|c|c|c|c|c|}
\hline \multirow[b]{2}{*}{ Question } & \multirow{2}{*}{$\begin{array}{c}\chi^{2} \\
\text { Value }\end{array}$} & \multirow[t]{2}{*}{ p-value } & $\begin{array}{c}\text { Strongly } \\
\text { Agree }\end{array}$ & Agree & Disagree & $\begin{array}{l}\text { Strongly } \\
\text { Disagree }\end{array}$ \\
\hline & & & $\%$ & $\%$ & $\%$ & $\%$ \\
\hline $\begin{array}{l}\text { 1. I experienced no difficulty in } \\
\text { adapting to my school. }\end{array}$ & 1 & 0.486 & 41.8 & 40.3 & 13.5 & 4.4 \\
\hline $\begin{array}{l}\text { 2. In our school, all learners, } \\
\text { irrespective of their cultural } \\
\text { background are treated the same. }\end{array}$ & 1 & 0.565 & 27.5 & 38.2 & 25.8 & 8.5 \\
\hline $\begin{array}{l}\text { Enrolling black learners in former } \\
\text { white schools has led to a drop in } \\
\text { standards. }\end{array}$ & 1 & 0.477 & 15.1 & 33.7 & 32.8 & 18.4 \\
\hline $\begin{array}{l}\text { 4. Educators have higher academic } \\
\text { expectations white learners than } \\
\text { learners from black learners. }\end{array}$ & 1 & 0.523 & 25.7 & 28.8 & 26.7 & 18.8 \\
\hline $\begin{array}{l}\text { 5. Black learners tend to be more } \\
\text { withdrawn than white learners } \\
\text { during group work and other class } \\
\text { activities. }\end{array}$ & 1 & 0.524 & 20.0 & 30.5 & 32.9 & 16.6 \\
\hline $\begin{array}{l}\text { 6. The failure and drop-out rate tend } \\
\text { to be higher among black learners } \\
\text { than white learners. }\end{array}$ & 1 & 0.539 & 27.8 & 36.4 & 22.9 & 12.9 \\
\hline $\begin{array}{l}\text { 7. I am more comfortable to be } \\
\text { taught by educators belonging to } \\
\text { my own culture }\end{array}$ & 1 & 0.489 & 18.5 & 42.6 & 20.5 & 18.4 \\
\hline $\begin{array}{l}\text { 8. I sometimes experience conflict } \\
\text { between what I am taught at } \\
\text { school and what I am taught at } \\
\text { home. }\end{array}$ & 1 & 0.475 & 18.6 & 42.5 & 23.3 & 15.6 \\
\hline $\begin{array}{l}\text { 9y friends who are not attending } \\
\text { historically white schools still } \\
\text { accepts me as a friend and has not } \\
\text { changed their attitude towards me. }\end{array}$ & 1 & 0.623 & 57.8 & 31.6 & 7.2 & 3.4 \\
\hline $\begin{array}{l}\text { 10. If I could choose, I would prefer to } \\
\text { attend a historically black school. }\end{array}$ & 1 & 0.518 & 18.0 & 16.5 & 29.1 & 36.4 \\
\hline
\end{tabular}

The difference is statistically significant if $\mathrm{P}<0.05$ 
Most of the learners (82.1\%) indicated that they have no difficulty in adapting at their school, contrary to views held by (Cross \& Mkwanazi-Twala,1998:28-30) believe that black learners' identity formation is adversely affected, because of the struggle they experience with adapting at these schools. The fact that learners indicated equitable treatment, in spite of their cultural background, may bode well for identity formation enhancement of these learners. The latter further highlight the potential influence, negative perceptions towards certain cultural groups held at schools, may have on the identity formation of learners. The cultural background of all learners is an important consideration in the teaching and learning process (Conklin, 2015:25). Learner participants (50.5\%) seem to concur with the literature that, black learners tend to be more withdrawn than white learners in class. Historically white schools dealt with integration in a manner, that has been characterised by asymmetry, in which white people are the bearers of preferred knowledge and blacks, by contrast, as the embodiment of inferior understanding of the world (McKinney, 2010:192). This state of affairs is hardly conducive for the formation of a positive identity. A total of $54.5 \%$ of learner participants indicated that their educators have higher academic expectations from white learners and that the failure and drop-out rate tend to be higher amongst black learners-this according to $64.2 \%$ of learners. These findings concur with the recent foregrounding of social justice and equity in educational the discourse (Cho, 2017:1). To this effect Świdzińska (2019:96) advises that teachers could assist learners by understanding their culture and supporting them in adapting to their new environment. The majority (61.1\%) of learners indicated that they are more comfortable to be taught by educators belonging to their own culture. The finding that an overwhelming percentage of black learners experienced conflict between what they are taught at school and home, respectively. These findings are echoed by the sentiments of (Erasmus \& Ferreira, 2002:30). They argue that children cannot be treated as learners in the normal sense without considering their immediate background and family history, as well as the impact of these factors on their reaction to the learning environment. Moosa (2018:57) supports this notion by insisting that aim of initial teacher education (ITE) programmes is "to prepare pre-service teachers to teach effectively in diverse classrooms".

In conclusion, although the literature suggests rejection of these learners by township school attending friends, the findings revealed the contrary. Correspondingly, the findings of the study dispute the argument presented by Erasmus and Ferreira (2002:31) that postulate that, when given a choice of schools, black learners would choose a school where all race groups are equally represented. The findings suggest that the majority $(65.5 \%)$ of black learners prefer attending historical white schools.

\section{Conclusion}

This study was meant to investigate the complexity of identity formation of black learners attending historically white high schools in the Northern Cape province of South Africa. Findings from the literature and empirical investigation indicated that some situational experiences encountered by black learners at these schools may well curtail the development a positive identity formation. The display of adverse effects, such as general adaptation challenges, unreceptive and unkind teacher behaviour, as having an effect on the identity formation of black learners. Educators are inherently responsible for assisting learners develop their identity. Hence, it is crucial that the critical pedagogical imperatives such as, low educator expectations (of black learners), the disjuncture between the home- and school education, as well as mitigating the high failure and drop-out rate, be addressed, in teacher education and continuous professional teacher development programmes.

\section{References}

Cho, H. (2017). Navigating the meanings of social justice, teaching for social justice, and multicultural education. International Journal of Multicultural Education, 19(2), 1-19.

Conklin, H. G. (2015). Preparing novice teachers educators in the pedagogy of teacher education. Action in Teacher Education, 37(4), 317-333.

Cross M \& Mkwanazi-Twala Z 1998. The dialectic of unity and diversity in education: Its implications for a nation curriculum in South Africa. In M Cross, Z Mkwanazi-Twala \& G Klein (eds). Dealing with diversity in South African education. Cape Town: Juta.

Erasmus P \& Ferreira G 2002. Black Grade 9 learners in historically white suburban schools and their experience of integration. South African Journal of Education, 22(1):28-35.

McKinney C 2010. Schooling in black and white: Assimilationist discourses and subversive identity performances in a desegregated South African girls' school. Race Ethnicity and Education, 13(2):191- 207. 
Moosa, M. (2018). Promoting quality learning experiences in teacher education: What mentor teachers expect from pre-service teachers during teaching practice. The Independent Journal of Teaching and Learning, 13(1), 57-68.

Northern Cape Department of Education. 2020. EMIS. Statistical Report. February 2020.

Ntuli S 1998. The Life-world of the black child in ex-model "C" schools. MEd. Durban: University of Zululand.

Świdzińska. A. 2019. Kultura i Edukacja. Ukrainian Students in Polish Schools: Selected Aspects of Adaptation on the Example of the City of Lublin. No. 4 (126), pp. 95-108. doi: 10.15804/kie.2019.04.06 www.kultura-i-edukacja.p 